\title{
Sağlık Sektöründe Kamu Özel Ortaklığı Modeli ve Adana Şehir Eğitim ve Araştırma Hastanesine Yönelik Bir Araştırma
}

\author{
PPP Model in Health Sector and a Research on the PPP Perceptions of Adana City Training and Research \\ Hospital Personnel
}

\author{
Zekiye PANGAL ÇALIŞKAN ${ }^{1}$, Hakan YAŞ ${ }^{2}$
}

\begin{abstract}
ÖZ
Bu çalışmanın amacı, kamu özel ortaklığı (KÖO) modeliyle yapılan Adana Şehir Eğitim ve Araştırma Hastanesinin çalışanlarının KÖO algılarında sosyodemografik özellikleri açısından farklılıklar bulunup bulunmadığını tespit etmektir. Hastane çalışanlarında ( $\mathrm{N}=5.297)$ basit tesadüfi örneklemeye gidilerek, araştırmaya katılımı kabul eden 364 sağlık çalışanına 59 soruluk bir ölçek uygulanmıştır. Yanıtlar doğrultusunda açıklayıcı faktör analizi yapılmış ve altı adet faktör elde edilmiştir. Çalışanların yaş, cinsiyet, eğitim durumu, unvan ve mesleki çalışma süresi değişkenlerine göre faktörlerin anlamlı bir fark oluşturup oluşturmadığına yönelik toplamda beş temel hipotez oluşturulmuştur. Ardından, her bir değişkenin barındırdığı grup sayısına göre alt hipotezler belirlenmiştir. Hipotezler öncelikle Kruskal Wallis testiyle sınanmış, 0,05 anlamlılık düzeyinin altında reddedilen sıfır hipotezlerine ayrıca Mann-Whitney U testi uygulanarak sıra ortalamaları karşılaştırılmıştır. Alg1 karşılaştırması sonuçlarının çalışanların yaş, cinsiyet, eğitim durumu, unvan ve mesleki çalışma süresi değişkenlerine göre farklılık arz ettiği; ancak, bağımsız değişkenlerin gruplarından bazıları arasında farklılık bulunmadı $\breve{1}$, bunların sifır hipotezlerinin reddedilemediği görülmüştür. 26 yaş altı çalışanların KÖO’yu daha çok eleştirdikleri, 41 ve üzeri yaşta olanların sağlık hizmetlerinin finansmanında sorunlar yaşandığı algısına sahip oldukları, mesleki çalışma süresi beş ve daha az olan sağlık çalışanlarının KÖO'yu daha az eleştirdikleri, üniversite mezunlarının sağlık hizmetlerinin sunumunu sorunlu gördükleri ve aynı sorunun yönetici olarak çalışanlarda da algılandığı sonuçlarına ulaşılmıştır.
\end{abstract}

Anahtar Kelimeler: Kamu-özel ortaklığı, Sağlık çalışanları, Şehir hastaneleri.

\begin{abstract}
The aim of this study is to determine whether there are differences in PPP perceptions of the personnel of the Adana City Training and Research Hospital, which is constructed with the Public Private Partnership (PPP) model, in terms of their sociodemographic characteristics. A scale of 59 questions was applied to 364 healthcare personnel who accepted to participate in the study among the Hospital personnel $(\mathrm{N}=5.297)$ by simple random sampling. Exploratory factor analysis is employed in accordance with the responses and data is broken up into six factors. Five basic hypotheses are constructed towards that whether these factors are significantly differentiated with respect to age, gender, graduation, position and professional time of the personnel. Then, sub-hypotheses are constructed in terms of the number of groups included in each variable. The hypotheses are tested by the Kruskal Wallis method at first. The Mann-Whitney U test is also employed to test the null hypotheses rejected under 0.05 significance level, and the mean ranks of the variables are compared. The results of the comparison of perceptions differ according to the variables of age, gender, graduation, title and professional time of the personnel; however, there is no difference between some of the groups of independent variables, their null hypothesis cannot be rejected. Some of the results obtained in this study can be summarized as the personnel under the age of 26 are more critical of PPP, 41 ages and older people perceives that there are problems in financing of health services, health personnel with a professional working time of maximum five criticizes PPP less, and the personnel having bachelors' degree consider the provision of health services problematic, and same problem is also perceived by the managerial personnel.
\end{abstract}

Keywords: City hospitals, Health personnel, Publicprivate partnership.

\footnotetext{
* Bu çalışma, 2019 yllında Trakya Üniversitesi Sağllk Bilimleri Enstitüsü Sağllk Yönetimi Anabilim Dalında yüksek lisans tezi olarak kabul edilmiştir.

${ }^{1}$ Hemşire, Zekiye PANGAL ÇALIŞKAN, Lüleburgaz Devlet Hastanesi, zekiyepangal@ gmail.com, ORCID:0000-0002-5293-4994

${ }^{2}$ Doç. Dr., Hakan YAŞ, Trakya Üniversitesi Sağlık Bilimleri Enstitüsü Sağlık Yönetimi ABD, hakanyas@trakya.edu.tr, ORCID: 0000-00016686-1899 
Sağlık sektöründe 1987 senesinde çıkan 3359 sayılı Sağlık Hizmetleri Temel Kanunu, Kamu Özel Ortaklığı (KÖO) modeline ilişkin resmi gelişme olarak görülmektedir. Daha sonra Numune Hastanesi fikrinin hayata geçirilmesiyle ülke dışından finansal kaynak temini başlamış, 1999 senesindeki Anayasa değişikliğine bağlı olarak yaygın hale gelmiştir. 2003 senesi itibariyle Sağlıkta Dönüşüm Programı kapsamında geliştirilen yenilikler ve düzenlemelere bağlı olarak temizlik ve yemek gibi hizmetlerde de diş kaynak alımı yoluyla özel sektörden destek almaya başlanmıştır. ${ }^{2}$ Sağlık Hizmetleri Temel Kanunu kapsaminda 2005 senesinde KÖO modeli yöntemlerinden olan yap-işletdevret (YID) modeli sağlık sistemi içerisine dâhil olmuş ve uygulamaya konmuştur. $\mathrm{Bu}$ dönemde özellikle sağlık sektöründe örneklendirilmeye çalışılan KÖO modeliyle kira bedelleri karşılığında sağlık tesislerinin yapımına başlanması, sağlık tesisi ve ek binaların bakım, onarım ve tamirinin gerçekleştirilmesi, tıbbi destek hizmet sunumlarının yapılması, tıbbi hizmetler haricinde kalan temizlik, güvenlik, yemekhane gibi hizmet sunumlarının gerçekleştirilmesi, sağlık tesislerinde bulunan tıbbi alet ve ekipmanlarının hazır konuma getirilmesi planlanmıştır. ${ }^{3} 2007$ senesinde bakanlığa bağlı KÖO Daire Başkanlığı biriminin açılması modele ilişskin ilgili birimlerin oluşturulmasına öncülük etmiştir. ${ }^{4}$ Türkiye'de bu modele ilişkin en önemli resmi adım 2013 senesinde 6428 sayılı Sağlık Bakanlığı (SB) tarafından Kamu Özel İş Birliği Modeli ile Tesis Yaptırılması, Yenilenmesi ve Hizmet Alınması ile Bazı Kanun ve Kanun Hükmünde Kararnamelerde Değişiklik Yapılması Hakkında Kanun ile ortaya konulmuştur. Kanun kapsamında model ile hizmete açılacak sağlık kurumları, SB tarafından belirlenen standartlara bağlı ihale yoluyla gerçek kişiler ya da özel hukuka tabi tüzel kişilere önceden belirlenmiş süreler ve bedeller üstünden kiralama karşılığında yaptırılacaktır. Projenin yürütülmesi ile ilgili görev alan özel sektör kuruluşları önceden belirlenmiş dönemlerde yapım ve işletme sorumluluklarını yerine getirirler. Devlet ise

\section{GİRIȘ}

bu sözleşme karşıllı̆ında şirkete uzun vadeli bir ödeme planiyla kira öder. ${ }^{5}$ Şehir hastanelerinin kirası ve hastanede çalışanların maaşları SB tarafından ve sağlık kurumunun döner sermaye gelirinden ödenmektedir. Böylece şehir hastanelerinin hazineye yük olmayacağ1 düşünülmektedir. ${ }^{6}$ Türkiye'de son yıllarda gerçekleştirilen büyük çaplı projeler bu model temel alınarak sürdürülmektedir. ${ }^{7}$

KÖO modeline göre, aşağıdaki koşullar esas alınarak projeler yürütülmektedir: ${ }^{8}$

1. Yapılacak olan sözleşmelerin süresi en fazla 49 yıldır. Fakat bu süre genelde 30 sene olarak hayata geçmektedir.

2. SB tarafindan ön proje ve temel şartnameye ilişkin ekler verilmektedir.

3. Projenin yapılacağı arazi bedelsiz olarak devlet tarafindan temin edilmektedir.

4. Projenin detaylandırılması ve diğer tüm ayrıntılar özel sektör tarafindan hazırlanmaktadır.

5. İhaleye teklif verenler arasından kazanan özel kuruluş sağlık tesisinin yapım işine başlanmaktadır.

Bazı kaynaklara göre şehir hastanelerinde; dal hastaneler entegre sağlık kampüslerinde toplanacak ve alanında uzman doktorlar şehir hastanesindeki tüm hastanelerde görevli olacaklarından, ülkedeki doktor azlığı sorunu hakkındaki sıkıntı çözülmüş olacağı iddia edilmektedir. Benzer şekilde laboratuvar ve röntgen gibi görüntüleme cihazlarının bir merkezde toplanması farklı hastanelere cihaz temini ihtiyacını ortadan kaldıracağı ileri sürülmektedir. ${ }^{9}$

Merkezî acil servis, yoğun bakım servisleri, eczaneler, ilaç depoları, geri dönüşüm merkezleri, atık yönetim merkezleri, otoparklar, çocuk oyun alanları gibi bölümler de bu yapıların içinde bulunacak ve bu bölümlerin de katkısı ile sağlık hizmetleri sunumunda hasta memnuniyeti üst seviyeye taşınabilecektir. Şehir hastanelerinde sağlık hizmetini sunan taraf özel sektör değildir. Finansman, tesis tasarımı ve inşa edilmesi 
konularında var iken; kamu, tıbbi hizmetleri sunan taraf olmaktadır. Diğer bir deyişle kamu özel sektör ile birlikte yürüttüğü proje kapsamında yalnızca hekimlik ve hasta bakımına ilişkin sağlık temelli hizmetlerin sunumunu yapacak, bunun yanındaki diğer tüm yan hizmet sunumları özel sektör tarafindan gerçekleştirilecektir. ${ }^{9}$ Bununla birlikte sağlık hizmetlerinin değerlendirilmesi açısından kamu, etkili ve öncü bir hizmet sunumu yerine getirmelidir. $^{10}$ Türkiye'de kanunlara göre tıbbi hizmet uygulamaları doğrudan devlet tarafindan sunulan hizmetler oldukları için KÖO projeleri kapsamında ele alınmamaktadır. Sağlık Bakanlığı tarafindan 2010'da yayınlanan araştırma raporunda yer alan sonuçlara göre, Türkiye'de verilen sağlık hizmetlerinin yüzde beşinde hizmet alımı yöntemi ile özel sektörden yararlanıldığ 1 bilgisine yer verilmiştir. ${ }^{2}$ Çekirdek tıbbi hizmetler kamu tarafindan görülecekken, tıbbi hizmetlere yardımcı nitelikte sterilizasyon, laboratuvar işlemleri, temizlik hizmetleri, tıbbi görüntüleme, bilgi ve veri işleme, personel ve sekreterlik hizmetleri, teknik destek hizmetleri, otelcilik hizmetleri, otopark ve kafeterya işletimi yüklenici firma tarafından gerçekleştirilir. Bunlar haricindeki hizmetler başhekimlik tarafından yürütülmekte ve her iki taraf da hizmetleri kendi personeli ile vermektedir. Bu kapsamda yüklenici tarafından sunulacak hizmetler P1 ve P2 hizmetleri olarak iki türdür. Bina ve arazi hizmetleri, olağanüstü bakım ve onarım, yer ve bahçe bakımı, ortak hizmetler yönetimi, mefruşat hizmeti ve diğer tıbbi ekipman destek hizmeti P1 hizmetleri arasındadır. Temizlik hizmetleri, güvenlik hizmeti, otopark hizmetleri; yemek ve çamaşırhane hizmetleri; atı yönetim hizmetleri, sterilizasyon ve dezenfeksiyon hizmetleri; hastane bilgi yönetim sistemi
(HBYS) uygulama ve işletme hizmeti; refakat ve hasta yönlendirme (veya resepsiyon) ile ilaçlama hizmetleri, laboratuvar hizmetleri, görüntüleme hizmetleri, rehabilitasyon hizmetleri ise P2 hizmetleridir. ${ }^{11}$ P1 hizmetleri karşılığında ödenecek kullanım bedeli SB bütçesinden karşılanmaktadır. Kullanım bedeli ihale sürecinde belirlenmektedir. P2 hizmetleri için ödenen hizmet bedeli hastanenin döner sermayesinden finanse edilmektedir. $\mathrm{Bu}$ hizmetlerin bedeli beş yılda bir piyasa testiyle değişmektedir. Böylece P2 hizmetlerinin fiyat riskini döner sermaye işletmeleri üstlenmektedir. ${ }^{12}$

Türkiye'de KÖO modeliyle finanse edilen toplam dokuz adet şehir hastanesi bugün faaliyettedir. Bunlardan Adana Şehir Eğitim ve Araştırma Hastanesi 1.550 yatak kapasiteli bir hastane olup, 2017 yılında açılmıştır. Toplamda 5.297 adet sağlık çalışanı bulunmaktadır. $^{13} \quad 1.512$ adet izolatörle dünyadaki en büyük sismik izolatörlü hastane olduğu bilinmektedir. Hastane modern teknoloji ve izolatörlerle muhtemel en yıkıcı deprem esnasında bile tüm çalışmalarını aksaklık yaşamadan devam ettirebilecektir.

KÖO'nun sağlık sektöründeki önemini gösteren bu bilgiler doğrultusunda; bu çalışmanın amacı, KÖO modeliyle yapılan Adana Şehir Hastanesi çalışanlarının KÖO algilarında, sosyo-demografik özellikleri açısından farklılıklar bulunup bulunmadığını tespit etmektir. $\mathrm{Bu}$ amaçla öncelikle veri ve yöntem açıklanacak, ardından da elde edilen bulgular ortaya konarak istatistiksel analiz sonuçlarına yer verilecektir. Tartışma kısmında ise çalışma kapsamında elde edilen sonuçlara yönelik literatür değerlendirilerek, çalışmayla benzer veya farklı yönleri ortaya konmaya çalışılacaktır.

\section{MATERYAL VE METOT}

Araştırma örneklemini KÖO modeliyle yapılan Adana Şehir Eğitim ve Araştırma Hastanesinde çalışan ve araştırmaya katılmaya gönüllü olan sağlık çalışanları oluşturmaktadır. Söz konusu hastanedeki yöneticilerle telefonla görüşülerek edinilen bilgilere göre, hastanede çalışan sağlık personeli sayısı 5.297 kişidir. Bununla birlikte Sağlık Yatırımları Genel Müdürlüğü 5.000 personelinin olduğunu bildirmektedir. ${ }^{13} 5.297$ dikkate alındığında dahi örneklem büyüklüğü 0,05 güven düzeyi ve 0,05 hata payında 359 olduğu için ${ }^{14}$ çalışmamızda 5.297 personel 
rakamı kullanılmıştır. Hastanede çalışan sağlık personelinin, KÖO ile yapılan ve hizmete açılan diğer hastanelerdeki sağlik çalışanlarından sayıca fazla olmasından dolayı çalışma kapsamına alınmıştır.

Araştırmanın örnekleminin tespit edilmesinde basit tesadüfi örnekleme yöntemi kullanılmış olup, 364 kişi ile anket çalışması tamamlanmıştır. Araştırmada kullanılan ölçek Keskin $^{15}$ tarafından geliştirilmiş olup, ankette sağlık çalışanlarının yaş, cinsiyet, eğitim, mesleki deneyim ve sağlık çalışanı görevi/pozisyonu şeklindeki sosyodemografik özellikleriyle ilgili beş soru, KÖO’ya ilişkin 54 soru bulunmaktadır. KÖO soruları 5'li Likert formundadır.

\section{İstatistiksel Analiz}

Ölçeğe önce STATA 14.1 programı yardımıyla doğrulayıcı faktör analizi yapılmış; ancak, verilen yanıtlar ile kullanılan ölçek için önerilen faktörlere uyum sağlanamadığ 1 için SPSS programında açıklayıcı faktör analizi gerçekleştirilerek yeni faktörler tanımlanmıştır. Ardından, araştırmada

oluşturulan

hipotezler nonparametrik bir test olan Kruskal Wallis $\mathrm{H}$ testi ile SPSS 23.0 programı kullanılarak sınanmıştır. Kruskal Wallis $\mathrm{H}$ testinde 0,05 düzeyinde reddedilen sıfır hipotezleri için, farklı olan bağımsız değişken grubunun hangisi olduğunun saptanabilmesi amaciyla, Mann-Whitney U testi de yapılmıştır.

\section{Araştırmanın Etik Yönü}

$\mathrm{Bu}$ araştırmanın uygulanabilmesi için Trakya Üniversitesi Tıp Fakültesi Dekanlığı Bilimsel Araştırmalar Etik Kurulundan 25.03.2019 tarih ve 06/27 sayılı kararla onay alınmıştır. Araştırmanın söz konusu hastanede gerçekleştirilebilmesi için Adana Valiliği İl Sağlık Müdürlüğünden 10.04.2019 tarih ve 60247264-799 sayılı kararla olur alınmıştır.

\section{Araştırmanın Kısıtılılıkları}

Araştırma Türkiye'deki dokuz şehir hastanesinden yalnızca birine uygulanmış olup, araştırma sonuçları yalnızca araştırma grubuna genellenebilmektedir. $\mathrm{Bu}$ sonuçlar takip eden bölümde ayrıntılı olarak ele alınmıştır.

\section{BULGULAR VE TARTIŞMA}

Sosyo-demografik bağımsız değişkenler yaş, cinsiyet, eğitim düzeyi, yıl olarak mesleki deneyim ve görev/pozisyon bilgileri edinilmiştir. Yaş değişkeninde katılımcılara herhangi bir gruplandirma yapilmadan doğrudan veri elde edilmiştir. Ancak, bu çalışma kapsamında yapılacak olan analizlerde yardımcı olması adına, yaş bağımsız değişkeninin yeniden düzenlenerek gruplandırılması gerekmiştir. Doğrudan elde edilen yaş değişkenleri için, bu kapsamda, SPSS Visual Binning menüsü aracılığıyla veri gruplandırılmasına gidilmiştir. Gruplandırma yapılırken, her ne kadar yaş grupları eşit aralıklı belirlenememiş olsa da grupların birbirine yaklaşık bir geçerli dağılım yüzdesi göstermesine dikkat edilmiştir. Gruplandırılmış yaş değişkenine göre 26 yaş altındaki katılımcılar toplamın yaklaşık $\% 20$ 'sine tekabül ederken, değişkenin modu \%22,3 oranında pay ile 30-34 yaş aralığıdır. 41 yaş ve üzerindeki katılımcılar ise toplamın yaklaşık \%17'sine karşılık gelmektedir. Anket çalışmasına katılan sağlık çalışanlarının \%37,9'u erkek (138), \%62,1'i (226) kadındır. Katılımcıların \%61,5'inin 10 yıla kadar bir sektör deneyimi bulunmaktadır. 20 yıldan fazla bir süredir sağlık sektöründe yer alan, diğer bir ifadeyle katılımcıların içerisindeki en deneyimli kesimin oranı \%11'dir. Sağlık çalışanlarının eğitim durumu incelendiğinde \%5,8'inin lise, \%77,7'sinin üniversite, \%16,5'inin yüksek lisans mezunu olduğu görülmekte olup, \%60,4'ü hemşire, $\% 32,1$ 'i diyetisyen, eczac1, acil tıp teknisyeni, laboratuvar teknisyeni, röntgen teknisyeni veya anestezi teknisyeni gibi sağlı personeli, $\% 6,3^{\prime}$ ü doktor ve $\% 1,1$ 'i yöneticidir.

Ölçeğin geri kalan soruları ise sağlık çalışanlarının KÖO algılarının ölçümüne ilişkin olup, 54 sorunun Cronbach's Alpha değeri $\alpha=0,768$ olarak bulunmuştur. KÖO alg1 ölçeği için yapılan açıklayıcı faktör analizine ilişkin olarak, Kaise-Meyer-Olkin (KMO) değeri 0,848 'dir. $\mathrm{Bu}$ değer örneklem büyüklüğün çok iyi olduğunu işaret etmektedir. Bartlett's testi sonuçları 
incelendiğinde ise, $\mathrm{X}^{2}=6501,955, \mathrm{df}=435$ ve $\mathrm{p}=0,000$ test istatistikleri elde edilmiş olup, bu bulgular değişkenler arasında korelasyon olduğu bilgisini vermektedir. Bu bağlamda, verilerin faktör analizine uygunluğu doğrulanmıştır.

Açıklayıcı faktör analizi sonuçlarına göre toplamda altı adet faktör oluşturulmuştur. $\mathrm{Bu}$ faktörlerin hipotezlerde ayrıntılı gösterimi yerine kısaca "KÖO Algısı" şeklinde özetlenmesi tercih edilmiştir. Belirlenen faktörlerden ilki olan "KÖO fayda ve verimliliği” toplam varyansin \%30,272'sini, ikinci faktör olan "KÖO eleştirileri" \%10,934'ünü, üçüncü faktör olan “Türkiye'de sağlık hizmetleri sunumu” \%8,625'ini, dördüncü faktör olan 'KÖO'nun istihdama etkisi” \%6,247'sini, beşinci faktör olan "sağlık hizmetleri finansman sorunları" \%5,209'unu ve altınc1 faktör olan "sağlık hizmetlerinin verimliliği” ise $\% 4,353$ 'ünü oluşturmaktadır.

Çalışmada aşağıda yer alan hipotezler Kruskal Wallis testiyle sınanmıştır:
$\mathrm{H}_{1}$ : KÖO alg1S1 yaş etkenine göre anlamlı bir farkl1lık göstermektedir.

$\mathrm{H}_{2}$ : KÖO algısı cinsiyet değişkenine göre anlamlı bir farklılık göstermektedir.

$\mathrm{H}_{3}$ : KÖO algısı eğitim durumu değişkenine göre anlamlı bir farklılık göstermektedir.

$\mathrm{H}_{4}$ : KÖO algısı görev/unvan değişkenine göre anlamlı bir farklılık göstermektedir.

$\mathrm{H}_{5}$ : KÖO algısı mesleki çalışma süresi değişkenine göre farklılık göstermektedir.

Bu hipotezlerin farksılık hipotezleri ise iki grup arasında istatistiksel olarak anlamlı bir farklılık olmadığına yöneliktir. Açıklayıcı faktör analizinde altı adet faktör elde edildiği için her bir hipotez bu faktörler temelinde test edilmiştir.

\section{Yaş - KÖO Algısı}

Kruskal Wallis testine göre, gruplandırılmış yaş değişkeni temelinde oluşturulan altı adet hipotezden dört tanesinin sıfir (farksızlık) hipotezi kabul edilirken, iki tanesinin farksızlık hipotezi reddedilmiştir.

Tablo 1. Yaş - KÖO Farklılığı Hipotez Test Özeti

\begin{tabular}{|c|c|c|c|}
\hline \multicolumn{2}{|c|}{ Sıfır Hipotezleri } & (p) & Karar \\
\hline \multicolumn{2}{|c|}{$\begin{array}{l}\text { KÖO Fayda ve Verimliliği faktörünün dağılımı, Yaş kategorileri } \\
\text { ile aynıdır. }\end{array}$} & 209 & $\mathrm{H}_{0}$ kabul \\
\hline \multicolumn{2}{|c|}{ KÖO Eleştirileri faktörünün dağılımı, Yaş kategorileri ile aynıdır. } & ,011 & $\mathrm{H}_{0}$ ret \\
\hline Grup 1 - Grup 2 & $\begin{array}{l}\text { Mann-Whitney U Test } \\
\text { İstatistiği }\end{array}$ & $\begin{array}{l}\text { Sira Ortalamas1 } \\
(\text { Grup } 1-\text { Grup 2) }\end{array}$ & Anlamlılık (Sig.) \\
\hline$"<=26 "-" 35-40 "$ & 2132,000 & $66,11-81,57$ & 0,028 \\
\hline$"<=26 "-" 41+"$ & 1730,000 & $60,53-74,64$ & 0,035 \\
\hline$"<=26 "-" 30-34 "$ & 1947,500 & $63,55-88,96$ & 0,000 \\
\hline “27 - 29” - “30 -34” & 2448,000 & $70,64-85,78$ & 0,036 \\
\hline \multicolumn{4}{|c|}{ kategorileri ile aynıdır. } \\
\hline \multicolumn{2}{|c|}{$\begin{array}{l}\text { KÖO’nun İstihdama Etkisi faktörünün dağılımı, Yaş kategorileri } \\
\text { ile aynıdır. }\end{array}$} & 261 & $\mathrm{H}_{0}$ kabul \\
\hline \multicolumn{3}{|c|}{$\begin{array}{l}\text { Sağlık Hizmetleri Finansman Sorunları faktörünün dağılımı, Yaş } \\
\text { kategorileri ile aynıdır. }\end{array}$} & $\mathrm{H}_{0}$ ret \\
\hline Grup 1 - Grup 2 & $\begin{array}{l}\text { Mann-Whitney U } \\
\text { Test İstatistiği }\end{array}$ & $\begin{array}{l}\text { Sira Ortalamas } \\
\text { (Grup } 1 \text { - Grup 2) }\end{array}$ & Anlamlılık (Sig.) \\
\hline "41+" - “35-40” & 1832,000 & $61,03-74,57$ & 0,046 \\
\hline$" 41+"$ - "<= 26" & 1544,000 & $56,31-76,06$ & 0,003 \\
\hline "41+" - “30-34" & 1530,000 & $56,08-83,11$ & 0,000 \\
\hline "41+" - "27 - 29" & 1262,000 & $51,69-82,17$ & 0,000 \\
\hline “35 - 40” - “27-29” & 2222,000 & $67,63-83,37$ & 0,026 \\
\hline $\begin{array}{l}\text { Sağlık Hizmetlerinin } \\
\text { kategorileri ile aynıdır. }\end{array}$ & iliği faktörünün dağılımı, Yaş &, 120 & $\mathrm{H}_{0}$ kabul \\
\hline
\end{tabular}


Gruplandırılmış yaş değişkeni ile yalnızca "KÖO eleştirileri" ve "sağlık hizmetleri finansman sorunları" faktörleri istatistiksel olarak anlamlı bir farklılık göstermektedir.

Sifir hipotezleri reddedilemeyen hipotezlere herhangi bir test uygulanmazken, sifir hipotezleri reddedilenlere ise ilgili hipotezin karar sonucunun hemen altında yer aldığ 1 şekilde Mann-Whitney $U$ testleri uygulanmıştır. Tabloya ise yalnızca MannWhitney $U$ testinde $\mathrm{p}<0,05$ koşulunu sağlayan, diğer bir ifadeyle, yalnızca istatistiki olarak anlamlı sonuç veren grupların test istatistikleri alınmıştır.

Tablo 1'deki KÖO eleştirileri - yaş karşılaştırmasına göre; 26 yaş ve daha küçük olan çalışanların sıra ortalaması, istatistiki olarak anlamlılık arz eden yaş gruplarından daha küçüktür. $\mathrm{Bu}$ açıdan, 26 yaş ve daha küçük gruptaki çalışanların KÖO'yu 30-34, $35-40$ ve 41 'den büyük yaş grubundaki çalışanlardan daha az eleştirdikleri söylenebilir. Yaşı 26 ve daha küçük olan sağlık çalışanlarının modelin sağlık hizmetleri sunumunda gereksiz bir uygulama olmadığını, özelleştirmeden farklı olduğunu düşündükleri söylenebilir. Diğer yaş grupları için $\mathrm{p}<0.05$ koşulunu sağlamadıklarından dolayı ilgili tabloda yer verilmemiştir.

Sıfır hipotezi reddedilen bir diğer hipotez olan "sağlık hizmetlerinin finansman sorunları" faktörüne ilişkin olarak 41 ve daha büyük yaşta olan çalışanların sıra ortalamaları daha düşük bulunmuştur. 41 ve üzeri yaştaki çalışanlar, sağlı hizmetlerinde finansman sorunları olduğunu, diğer yaş gruplarına göre daha az kabul etmektedirler. 41 ve üzeri yaşa sahip olan çalışanların, Türkiye'de sağlık yatırımlarına ayrılan genel bütçe finansman imkanlarını yeterli bulduğu söylenebilir. Yaş grubu 27-29 olan çalışanların 35-40 yaş grubunda çalışanlara göre sağlık hizmetlerinin finansmanı konusunda daha fazla sorun olduğuna kanaat getirdikleri ileri sürülebilir.

\section{Cinsiyet - KÖO algısı}

Çalışmanın iki sayılı hipotezi doğrultusunda KÖO ölçeğine katılımcıların verdikleri yanitlar ile cinsiyetleri arasinda anlamlı bir alg1 farklılığ1 bulunup bulunmadığına ilişkin test sonuçları Tablo 2 'de yer almaktadır.

Tablo 2. Cinsiyet ile KÖO Algıları Arasındaki Farklıı̆̆a İlişkin Hipotez Test Özeti

\begin{tabular}{|c|c|c|}
\hline Sıfir Hipotezleri & (p) & Karar \\
\hline $\begin{array}{l}\text { KÖO Fayda ve Verimliliği faktörünün dağılımı, Cinsiyet } \\
\text { kategorileri ile aynıdır. }\end{array}$ &, 084 & $\mathrm{H}_{0}$ kabul \\
\hline $\begin{array}{l}\text { KÖO Eleştirileri faktörünün dağılımı, Cinsiyet kategorileri ile } \\
\text { aynıdır. }\end{array}$ & ,000 & ret \\
\hline $\begin{array}{l}\text { Mann-Whitney U } \\
\text { Test İstatistiği }\end{array}$ & $\begin{array}{l}\text { as1 } \\
\text { p 2) }\end{array}$ & Anlamlılık (Sig.) \\
\hline "Erkek - Kadın" & 26 & 0,000 \\
\hline $\begin{array}{l}\text { Türkiye'de Sağlık Hizmetleri Sunumu faktörünün dağılımı, } \\
\text { Cinsiyet kategorileri ile aynıdır. }\end{array}$ & ,925 & kabul \\
\hline $\begin{array}{l}\text { KÖO’nun İstihdama Etkisi faktörünün dağılımı, Cinsiyet } \\
\text { kategorileri ile aynıdır. }\end{array}$ & ,988 & kabul \\
\hline $\begin{array}{l}\text { Sağlık Hizmetlerinin Finansman Sorunları faktörünün dağılımı, } \\
\text { Cinsiyet kategorileri ile aynıdır. }\end{array}$ & ,895 & kabul \\
\hline $\begin{array}{l}\text { Sağlık Hizmetlerinin Verimliliği faktörünün dağılımı, Cinsiyet } \\
\text { kategorileri ile aynıdır. }\end{array}$ & ,433 & kabul \\
\hline
\end{tabular}

Tablo 2'ye göre yalnızca "KÖO eleştirileri” algısı ile kişilerin cinsiyeti arasında anlamlı bir farklılık bulunmaktadır. $\mathrm{Bu}$ farklılığın yönü ilgili hipotezin hemen altındaki istatistiklerde yer almaktadır.
Erkeklerin KÖO eleştirileri algısına ilişkin ortalaması kadınlara göre daha yüksektir. Bu nedenle, erkeklerin kadınlara göre KÖO'yu daha çok eleştirmekte oldukları ifade edilebilir. 


\section{Eğitim Durumu - KÖO Algısı}

Üç sayılı hipotez bağlamında, katılımcıların KÖO algılarının, eğitim durumlarına göre farkl1lık gösterip göstermediği test edilmiştir. Oluşturulan alt hipotezlere ilişkin sonuçlar Tablo 3'te yer almaktadır.

Tablo 3. Eğitim Durumu ile KÖO Algıları Arasındaki Farklılığa İlişkin Hipotez Test Özeti

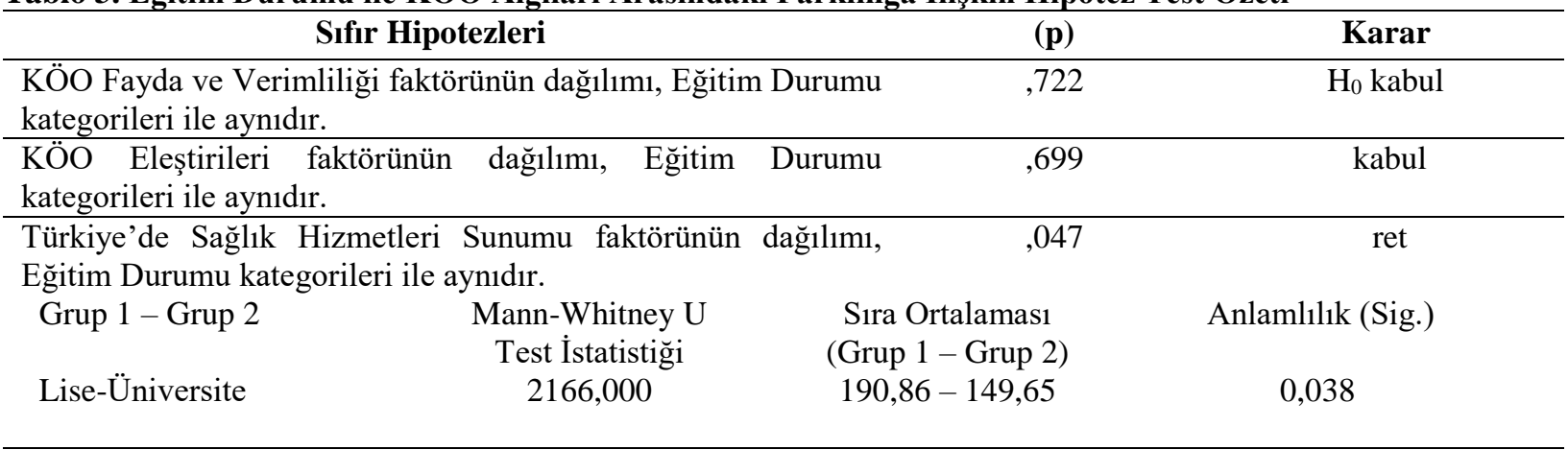

\begin{tabular}{lccr}
\hline \multicolumn{2}{l}{ KÖO’nun İstihdama Etkisi faktörünün dağılımı, Eğitim Durumu } &, 001 & ret \\
kategorileri ile aynıdır. & Mann-Whitney U & Sira Ortalaması & Anlamlılık (Sig.) \\
Grup 1 - Grup 2 & Test İstatistiği & (Grup 1 - Grup 2) & 0,001 \\
& 1648,000 & $89,48-157,18$ & 0,026 \\
Lise - Üniversite & 6937,000 & $146,12-177,49$ &
\end{tabular}

\begin{tabular}{|c|c|c|c|}
\hline \multicolumn{3}{|c|}{$\begin{array}{l}\text { Sağlık Hizmetlerinin Finansman Sorunları faktörünün dağılımı, } \\
\text { Eğitim Durumu kategorileri ile aynıdır. }\end{array}$} & ret \\
\hline Grup 1 - Grup 2 & $\begin{array}{l}\text { Mann-Whitney U } \\
\text { Test İstatistiği }\end{array}$ & $\begin{array}{l}\text { Sira Ortalamas1 } \\
\text { (Grup } 1 \text { - Grup 2) }\end{array}$ & Anlamlılık (Sig.) \\
\hline Lise - Yüksek lisans & 440,000 & $31,95-44,17$ & 0,040 \\
\hline Lise - Üniversite & 1580,000 & $86,24-157,42$ & 0,000 \\
\hline $\begin{array}{l}\text { Sağlık Hizmetlerinin Verin } \\
\text { Durumu kategorileri ile aynı }\end{array}$ & gi faktörünün dağ & ğitim & ret \\
\hline Grup 1 - Grup 2 & $\begin{array}{l}\text { Mann-Whitney U } \\
\text { Test İstatistiği }\end{array}$ & $\begin{array}{l}\text { Sira Ortalamas1 } \\
\text { (Grup } 1-\text { Grup 2) }\end{array}$ & Anlamlılık (Sig.) \\
\hline Yüksek lisans -Üniversite & 6673,000 & $141,72-178,42$ & 0,009 \\
\hline
\end{tabular}

Tablo 3'e göre altı faktör için oluşturulan alt hipotezlerden KÖO fayda ve verimliliğinin eğitim durumu değişkenine göre farklılık göstermediği hipotezi ile KÖO eleştirilerinin eğitim durumu değişkenine göre farklilik göstermediği hipotezleri reddedilememiştir. Diğer dört alt hipotezin sıfır hipotezleri ise reddedilmiş olup, bu faktörler ile katılımcıların eğitim durumları istatistiksel olarak anlamlı farklılık göstermektedir. Farksızlık hipotezleri reddedilen dört hipotezin, yalnızca istatistiki olarak anlamlı sonuç veren ikili karşılaştırma tabloları da Tablo 3'teki ilgili hipotezin altında ayrı ayrı yer almaktadir.

"Türkiye'de sağlık hizmetlerinin sunumu" faktörü ve eğitim durumu arasındaki ilişkiye bakıldığında, üniversite mezunlarının sıra ortalamasının lise mezunlarının sira ortalamasından daha küçük olduğu görülmektedir. Buna göre üniversite mezunu çalışanların Türkiye'de sağlık hizmetleri sunumunu, lise mezunları çalışanlara göre daha yetersiz bulduğu söylenebilir. Üniversite mezunlarının Türkiye'de sağlık hizmetlerinden herkesin eşit şekilde yararlandığ 1 ve sağlık hizmetinden halkın memnun olduğu görüşüne daha az katıldıkları söylenebilir.

Lise mezunu çalışanlar KÖO'nun istihdama etkisinin olduğunu diğer çalışanlara göre daha az kabul etmektedir. Üniversite mezunu çalışanların ise diğer çalışanlara göre KÖO'nun istihdam üzerinde daha etkili 
olacağını düşündükleri söylenebilir.

Üniversite mezunu sağlık çalışanlarının KÖO modelinin daha çok kişinin iş sahibi olmasını sağlayarak istihdamı arttıracağını düşündükleri ileri sürülebilir.

Sağlık hizmetlerinin finansman sorunları açısından, lise mezunu çalışanlar sağlik hizmetlerinde finansman sorunları olduğunu diğer çalışanlara göre daha az kabul etmektedirler. Lise mezunu çalışanların Türkiye'de sağlık hizmeti sunumunu hem üniversite hem de yüksek lisans mezunlarına göre yeterli bularak sağlık yatırımlarına ayrılan genel bütçe finansman imkanlarını yeterli buldukları ifade edilebilir.

Sağlık hizmetlerinin verimliliği faktörü bakımındansa, yüksek lisans mezunlarının sıra ortalaması üniversite mezunlarından düşük bulunmuştur. Bazı çalışmalarda sağlık yöneticilerinin \%82'sinin sağlik yönetimi eğitimi almadığı bulgusuna ulaşılmıştır. Hatta bu şekildeki yanlış istihdam politikaları nedeniyle çalışanların özel sağlık kuruluşlarına veya meslek dışı alanlara yöneldiği ifade edilmektedir. ${ }^{16}$ Yüksek lisans mezunlarının üniversite mezunlarına göre sağlık hizmetlerinin kalitesini ve verimliliğini yeterli düzeyde bulmadığı ileri sürülebilir. Diğer eğitim düzeyleri arasında ise anlamlı bir farklılık bulunmamaktadır. "KÖO fayda ve verimliliği" ile "KÖO eleştirileri” faktörleri, bağımsız değişkenler açısından farklılık sunmamaktadır.

\section{Görev - KÖO Algısı}

Çalışmanın dört sayılı hipotezi kapsamında, katılımcıların KÖO algılarının, çalıştıkları pozisyona/görevlerine göre farkl1lık gösterip göstermediği test edilmiştir. KÖO algısını ölçen anketin, faktörler temelinde oluşturulan alt hipotezler hakkındaki sonuçları Tablo 4'te gösterilmektedir.

Tablo 4. Katılımcıların Görevleri ile KÖO Algıları Arasındaki Farklılığa İlişkin Hipotez Test Özeti

\begin{tabular}{|c|c|c|c|}
\hline \multicolumn{2}{|c|}{ Sifır Hipotezleri } & (p) & Karar \\
\hline \multicolumn{4}{|c|}{ Kurumundaki Göreviniz kategorileri ile aynıdır. } \\
\hline \multicolumn{2}{|c|}{$\begin{array}{l}\text { KÖO Eleştirileri faktörünün dağılımı, Sağlık Kurumundaki } \\
\text { Göreviniz kategorileri ile aynıdır. }\end{array}$} & ,090 & $\mathrm{H}_{0} \mathrm{kabul}$ \\
\hline \multicolumn{2}{|c|}{$\begin{array}{l}\text { Türkiye'de Sağlık Hizmetleri Sunumu faktörünün dağılımı, } \\
\text { Sağlık Kurumundaki Göreviniz kategorileri ile aynıdır. }\end{array}$} & 002 & $\mathrm{H}_{0}$ ret \\
\hline Grup 1 - Grup 2 & $\begin{array}{l}\text { Mann-Whitney U } \\
\text { Test İstatistiği }\end{array}$ & $\begin{array}{l}\text { Sira Ortalamas1 } \\
\text { (Grup 1 - Grup 2) }\end{array}$ & Anlamlılık (Sig.) \\
\hline Yönetici-Sağlık Personeli & 24,000 & $8,50-62,79$ & 0,002 \\
\hline Yönetici - Hemşire & 27,500 & $9,38-114,38$ & 0,001 \\
\hline Yönetici - Doktor & 000 & $2,50-16,00$ & 0,000 \\
\hline Sağlık Personeli - Doktor & 1024,500 & $67,76-84,46$ & $0,071^{*}$ \\
\hline \multicolumn{4}{|c|}{ Kurumundaki Göreviniz kategorileri ile aynıdır. } \\
\hline \multicolumn{3}{|c|}{$\begin{array}{ll}\text { Sağlık Hizmetlerinin Finansman Sorunları faktörünün dağılımı, } & \text {,007 } \\
\text { Sağlık Kurumundaki Göreviniz kategorileri ile aynıdır. } & \end{array}$} & $\mathrm{H}_{0}$ ret \\
\hline Grup 1 - Grup 2 & $\begin{array}{lr}\text { Mann-Whitney U } & \text { Sura } \\
\text { Test İstatistiği } & \text { (Grup }\end{array}$ & $\begin{array}{l}\text { Sira Ortalamas1 } \\
\text { (Grup } 1 \text { - Grup 2) }\end{array}$ & Anlamlılık (Sig.) \\
\hline Sağlık personeli-Hemşire & 10295,000 & $146,99-180,70$ & 0,002 \\
\hline Sağlık personeli- Yönetici & 81,000 & $59,69-99,25$ & 0,026 \\
\hline $\begin{array}{l}\text { Sağlık Hizmetlerinin Verim } \\
\text { Kurumundaki Göreviniz kate }\end{array}$ & $\begin{array}{l}\text { i faktörünün dağılımı, Sağlık } \\
\text { leri ile aynıdır. }\end{array}$ & ,090 & $\overline{\mathrm{H}_{0} \mathrm{kabul}}$ \\
\hline
\end{tabular}

* Kruskal Wallis testinde istatistiki olarak anlamlı çıkmasına rağmen, sıra ortalama farkını bulmak için yapılan Mann-Whitney U Testinde anlamlı sonuç elde edilememiş olup, yorumlanmamıştır.

Tablo 4'e göre altı alt hipotezden yalnızca katılımcıların Türkiye' de sağlık hizmetlerinin sunumuna dair algılarının sağlık kurumundaki görevlerine göre algı farklılığı göstermediğine ilişkin hipotez ile sağlı hizmetlerinin finansman sorunlarına dair algılarının yine sağlık kurumundaki görevlerine göre alg1 
farklılığ1 göstermediğine ilişkin sıfır hipotezleri reddedilmiştir. Diğer hipotezler içinse gruplar arasında istatistiksel olarak anlamlı bir algı farklılığı olmadığı sonucuna ulaşılmıştır.

Tablo 4'e göre, Türkiye'de sağlık hizmetleri sunumu bakımından, yönetici pozisyonunda çalışanların sıra ortalaması diğer tüm görevlerde çalışanlardan daha düşük bulunmuştur. Buna göre yöneticilerin Türkiye'de sağlık hizmetleri sunumunu diğer çalışanlara göre daha yetersiz bulduğu söylenebilir. Yöneticilerin sağlık harcamaları için devletin yeterli ödenek ayırdığına, sağlık hizmetlerinden herkesin eşit şekilde yararlandığına ve sağlık hizmetinden halkın memnun olduğuna daha az katıldıkları söylenebilir.

"Sağlık hizmetlerinin finansman sorunları" faktörü açısından, sağlık personeli olarak görev yapanların sıra ortalaması hemşire ve yönetici pozisyonunda çalışanlardan daha düşük bulunmuştur. Buna göre sağlık personellerinde sağlık hizmetlerinin finansman sorunlarının daha az olduğu yönünde bir görüş hâkim olduğu söylenebilir. Sağlık personeli olarak görev yapanların Türkiye'de sağlık hizmetleri sunumunu daha yeterli bulduğu ve projelerin finansman sıkıntısı sebebiyle zamanında bitirilemediğine katılmadıkları söylenebilir. Hemşireler sağlık personeline göre sağlık hizmetlerinin finansmanında daha çok sorun olduğunu belirtmektedirler. Yöneticiler de sağlık personellerine göre sağlik hizmetlerinin finansmanını daha sorunlu görmektedir.

\section{Mesleki Çalışma Süresi - KÖO Algısı}

Oluşturulan beşinci hipotez doğrultusunda, katılımcıların KÖO algılarının, bu sektördeki toplam mesleki çalışma sürelerine göre farkl1lık gösterip göstermediği denenmiştir. KÖO ölçeği için oluşturulan altı adet faktöre ilişkin oluşturulan alt hipotezlere dair sonuçlar Tablo 5'te yer almaktadır.

Tablo 5. Mesleki Çalışma Süresi ve KÖO Algıları Arasındaki Farklılığa İlişkin Hipotez Test Özeti

\begin{tabular}{|c|c|c|c|c|}
\hline \multicolumn{3}{|c|}{ Sıfır Hipotezleri } & (p) & Karar \\
\hline \multicolumn{3}{|c|}{$\begin{array}{l}\text { KÖO Fayda ve Verimliliği faktörünün dağılımı, Mesleki Çalışma } \\
\text { Süresi kategorileri ile aynıdır. }\end{array}$} & ,107 & $\mathrm{H}_{0} \mathrm{kabul}$ \\
\hline \multicolumn{3}{|c|}{$\begin{array}{l}\text { KÖO Eleştirileri faktörünün dağılımı, Mesleki Çalışma Süresi } \\
\text { kategorileri ile aynıdır. }\end{array}$} & ,000 & ret \\
\hline Grup 1 - Grup 2 & $\begin{array}{l}\text { Mann-Whitney U } \\
\text { Test İstatistiği }\end{array}$ & \multicolumn{2}{|c|}{$\begin{array}{l}\text { Sira Ortalamas1 } \\
\text { (Grup } 1-\text { Grup 2) }\end{array}$} & Anlamlılık (Sig.) \\
\hline “0-5”-“6-10" & 4475,500 & \multicolumn{2}{|c|}{$95,26-126,41$} & 0,000 \\
\hline “0-5”-“20+” & 1401,000 & \multicolumn{2}{|c|}{$64,51-85,48$} & 0,006 \\
\hline “0-5"-“"11-15" & 1874,000 & \multicolumn{2}{|c|}{$69,24-97,19$} & 0,000 \\
\hline “0-5”-“16-20” & 1297,000 & \multicolumn{2}{|c|}{$63,47-90,62$} & 0,000 \\
\hline \multicolumn{3}{|c|}{$\begin{array}{l}\text { Türkiye'de Sağlık Hizmetleri Sunumu faktörünün dağılımı, } \\
\text { Mesleki Çalışma Süresi kategorileri ile aynıdır. }\end{array}$} & ,707 & kabul \\
\hline \multicolumn{4}{|c|}{$\begin{array}{l}\text { KÖO’nun İstihdama Etkisi faktörünün dağılımı, Mesleki } \\
\text { Çalışma Süresi kategorileri ile aynıdır. }\end{array}$} & ret \\
\hline Grup 1 - Grup 2 & $\begin{array}{l}\text { Mann-Whitney U } \\
\text { Test İstatistiği }\end{array}$ & \multicolumn{2}{|c|}{$\begin{array}{l}\text { Sira Ortalamas1 } \\
\text { (Grup } 1-\text { Grup 2) }\end{array}$} & Anlamlılık (Sig.) \\
\hline “0-5”-“6-10” & 4973,500 & \multicolumn{2}{|c|}{$100,24-122,39$} & 0,011 \\
\hline “0-5"-“'11-15” & 2088,000 & \multicolumn{2}{|c|}{$71,38-93,50$} & 0,003 \\
\hline \multicolumn{4}{|c|}{$\begin{array}{l}\text { Sağlık Hizmetlerinin Finansman Sorunları faktörünün dağılımı, } \\
\text { Mesleki Çalışma Süresi kategorileri ile aynıdır. }\end{array}$} & ret \\
\hline Grup 1 - Grup 2 & $\begin{array}{l}\text { Mann-Whitney U } \\
\text { Test İstatistiği }\end{array}$ & \multicolumn{2}{|c|}{$\begin{array}{l}\text { Sira Ortalamas } 1 \\
\text { (Grup } 1-\text { Grup 2) }\end{array}$} & Anlamlılık (Sig.) \\
\hline “16-20”-“11-15" & 816,000 & \multicolumn{2}{|c|}{$40,93-57,43$} & 0,005 \\
\hline “16-20”-“6-10” & 1540,000 & \multicolumn{2}{|c|}{$58,17-92,08$} & 0,000 \\
\hline “16-20”-“0-5” & 1376,000 & \multicolumn{2}{|c|}{$54,26-78,74$} & 0,001 \\
\hline \multicolumn{4}{|c|}{$\begin{array}{ll}\text { Sağlık Hizmetlerinin Verimliliği faktörünün dağılımı, Mesleki } & , 090 \\
\text { Çalışma Süresi kategorileri ile aynıdır. } & \end{array}$} & kabul \\
\hline
\end{tabular}

$\mathrm{Bu}$ tabloya göre alt1 adet alt hipotezden katılımcıların KÖO eleştirileri, KÖO'nun istihdama etkisi ve sağlik hizmetleri finansman sorunlarına ilişkin algıları, toplam 
mesleki çalışma sürelerine göre algı farklılığı göstermektedir. Diğer alt hipotezlerin farksızlık hipotezleri ise reddedilememiş olup, bu faktör algıları ile kişilerin mesleki çalışma süreleri arasında istatistiksel olarak anlamlı bir fark bulunmadığı sonucuna ulaşılmıştır.

KÖO eleştirilerine dair katılımcıların algısı, mesleki çalışma süresi beş yıla kadar olanlarla diğer süre gruplarına göre istatistiksel olarak anlamlı bir alg1 farklılığı arz etmektedir. Başka bir ifadeyle, bu süre grubundakilerin KÖO'ya yönelik eleştiri konusundaki algısı diğer mesleki süre gruplarından farklılık sunmaktadır. Ancak, diğer çalışma sürelerine dahil olan katılımcıların aynı alg1 konusunda birbirleri arasında bir alg1 farklılığı bulunmamaktadır. Beş yıla kadar mesleki çalışma süresi grubuna dahil olanların diğerlerinden farklılı̆̆ Whitney U ikili karşılaştırma testinde net bir biçimde kendini göstermektedir. 0-5 yıl aras1 mesleki deneyime sahip çalışanların sıra ortalaması diğer gruplara göre düşük bulunmuştur. Buna göre beş yıla kadar çalışma süresi olanların KÖO'yu daha az eleştirdikleri söylenebilir. Beş yıla kadar mesleki deneyime sahip çalışanların KÖO modeli ile gelecekteki kamu gelirlerinin şimdiden ipotek altına alındığına daha az katıldığı, özelleştirme olmadığını ve gerekli bir uygulama olduğunu düşündükleri söylenebilir.

KÖO'nun istihdama etkilerine ilişkin katılımcıların algılarının, Beş yıldan az mesleki deneyim sahip grup ile 6-10 y1llk mesleki deneyime sahip olan grup ve yine beş yıldan az mesleki deneyim sahip grup ile 1115 yıllık meslek deneyimine sahip olan grup arasında istatistiksel olarak anlamlı bir alg1 farklılı̆̆1 bulunmaktadır. Diğer grupların arasında ise istihdam konusunda anlamlı bir alg1 farklılığ 1 bulunmamaktadır. 0-5 yıl mesleki deneyime sahip çalışanların sıra ortalaması daha düşük bulunmuştur. Beş yıla kadar mesleki çalıșma süresi olanlar, 6-10 yıl ve 11-15 yıl çalışma süresi olanlara göre KÖO'nun istihdama daha az etkisi olacağını düşünmektedir.
16-20 y1l arasında sağlik sektöründe çalışmakta olanlar, sağlık hizmetlerinin finansman sorunlarına dair, 11-15 arasında, 610 arasında ve beş yıldan az mesleki deneyime sahip olanlara göre farklı algıya sahiptirler. Aynı grubun, 20 yılın üzerinde sağlık sektöründe çalışmakta olanlara göre aynı konuda istatistiksel olarak anlamlı bir alg1 farklılığ 1 yoktur. 16-20 yıl aras1 mesleki deneyime sahip çalışanların sıra ortalamasının daha düşük olduğu bulunmuştur. 16-20 yıl arası deneyimi olan çalışanlar, sağlık hizmetlerinde finansman sorunları olduğunu, 0-5, 6-10, 11-15 yıl mesleki çalışma süresi olanlara göre daha az kabul etmektedirler.

1980 sonrası değişen piyasa ekonomisi anlayışını takiben sağlık hizmetleri de küreselleşmiş ve özelleştirilmiş, devletin bu piyasaya müdahalesi azalmıştır. ${ }^{17} \mathrm{Bu}$ bağlamda sağlık hizmetleri için finansman ihtiyacının artması, devlet bütçelerinin bu ihtiyacı karşılayamaz hale gelmesi yeni bir finansman arayışı içine girmelerine sebep olmuştur. Böylece ortaya çıkan KÖO modeli uygulamaya konmuştur.

Çalıșma Türkiye'de sağl1k sektöründe son y1llarda uygulanmaya başlanan yeni bir finansman yöntemi olan KÖO modelini incelemek, KÖO ile yapılan Adana Şehir Eğitim ve Araştırma Hastanesindeki sağlık çalışanlarının KÖO modeline ilişkin algılarını belirli boyutlar çerçevesinde değerlendirerek ortaya koymak amaciyla yapılmıştır. Aşağıda belirtilen çalışmalar da KÖO ve şehir hastanelerine yönelik araştırmalardır.

Çınar ve arkadaşları şehir hastanelerinde sağlik hizmetlerinin sunumunda hizmet memnuniyetini incelenmiș ve şehir hastanelerinde fiziki imkanların yüksek olmasına rağmen hekim azlığı sebebiyle hastaların sıra bekleme sürelerinin uzun olduğu bulgusuna ulaşmışlardır. Genel anlamda şehir hastanelerinde hizmet memnuniyeti yüksek bulunan çalışmada yöneticilerin diğer çalıșan gruplara oranla hasta ve yakınlarına hoşgörülü ve saygılı davranma oranı daha düşük bulunmuştur. ${ }^{18}$

Medhekar, araştırmasında Hindistan'da sağllk hizmetleri sunumunda KÖO modeli ile özel sektörün rolünü ve sağlık turizmine 
etkilerini incelemiştir. Hindistan bir yandan yabanc1 hastalara birinci sinıf tıbbi tedavi hizmeti sunarken diğer yandan yoksulluk içinde yaşayan milyonlarca insan için birinci basamak sağlık hizmetlerine ve altyapıya eşit erişim sağlamakta zorlanmaktadır. KÖO projeleri ile yapilan hastanelerden sadece zenginlerin ve yabanciların hizmet alabildiğini belirten araştırmacı sağlık turizmini destekleyen hastanelerden kırsal ve kentsel alanda yaşayan, zengin ve fakir herkesin eşit faydalanamadığına değinmiștir. ${ }^{19}$

Baş, KÖO hakkında hizmet sunucuları ve yararlanıcılarının görüşlerini araştırmış ve yöneticilerin diğer tüm sağlık çalışanlarına göre model hakkında daha pozitif bakış açısına sahip olduğu sonucuna ulaşmıştır. Baş, KÖO modeli hakkında sağlık çalışanları için daha çok seminer, konferans ve bilgilendirme yapılması gerektiğine değinmiştir. Sağlık hizmeti sunucuları açısından şehir hastanelerinin devlet hastanelerine göre daha kaliteli hizmet sunduğu ve hasta memnuniyetinin arttığını savunmuştur. Sağlık çalışanları görüşlerine göre şehir hastanelerinde yönetimin sadece kamuya ait olması gerektiği görüşünün hâkim olduğu bulunmuştur. ${ }^{20}$

İran'da sağlık hizmeti sunumunda KÖO uygulamalarını desteklemek ve geliştirmek için stratejiler geliştirmek üzerine bir çalışma yapan Barati ve arkadaşları, politika ve yasalardaki değişiklikler, sosyo-kültürel değişiklikler, mevcut mekanizmaların ve süreçlerin düzeltilmesi ve finansal ve sermaye kapasitesi geliştirme gibi çeşitli faktörlerin en etkili stratejiler olduğunu belirtmişlerdir. Modelin İran'da başarılı olabilmesi için daha kapsamlı çalışmaların yapılması gerektiğini belirterek mevcut sonuçların uluslararası veriler ve örneklerle karşılaştırmasını önermişlerdir. ${ }^{21}$

Top ve Sungur Türkiye'de şehir hastanelerinde KÖO uygulamasinı paydaşların görüşleri üzerinden değerlendirmiştir. Araştırmaya göre KÖO'nun Türkiye'de sağlık sektöründe finansal açıdan uygulanabilirliği ile ilgili olumlu görüşler elde edilmiştir. Katılımcıların çoğunluğuna göre model, Türkiye'de sağlık sektörünün alt yapısı için uygun bir finansman modeli olarak belirtilmiştir. Kamu ve özel sektör paydaşları konu ile ilgili olumlu görüşler bildirirken sivil toplum kuruluşları temsilcilerinin olumsuz görüşlere sahip olduğu belirtilmiştir. Araştırmaya katılanların büyük çoğunluğu özel sektörün altyapı inşası için desteğinin önemli olduğunu ve yüksek teknoloji ekipmanı tedarik etmek için özel sektörle iș birliği yapmanın doğru olduğunu belirtmiştir. Araştırmada özel sektörün desteğinin sadece altyapı desteği ile sınırlı kalması gerektiğine değinilerek, özel sektörün destek hizmetleri kontrol etmesi halinde yüksek kar elde etmeyi hedefleyeceği vurgulanmıştır. ${ }^{22}$

Tenşi, KÖO uygulaması olan şehir hastanelerini başhekim, başhekim yardımcıları, müdür ve müdür yardımcıları tarafından değerlendirmiştir. Katılımcıların model ile ilgili yeterli bilgiye sahip olmadıkları bulgusuna ulaşan araştırmacı, farklı dal hastanelerinin aynı kampüs içinde olmasının hizmeti alanlar açısından daha ekonomik olacağını belirtmiştir. Şehir hastanelerinde modern ve kaliteli hizmet sunumu olacağını ve sağlı turizmine katkı sağlayacağını savunmuştur. Çalışma bulgularında şehir hastanelerinde yönetimin tamamen kamuya ait olması gerektiği önerilmiştir. ${ }^{23}$

Lopez ve arkadaşlarının Alzira modeli hakkındaki çalışmasında KÖO'nun genel olarak kamu hizmeti sağlayıcılarından daha iyi performans sergilemediği belirtilmiştir. Araştırmada Alzira Hastanesi'nin emsallerine göre daha kötü performans gösterdiği ve modelin başarılı olmadığ ulaşılmıştır. Yapılan çalışmada Alzira'daki deneyimlerin uluslararası örneklerin aksine teknik verim açısından istatistiksel olarak daha kötü sonuçlandığı belirtilmiştir. ${ }^{24}$

Gökbulut çalışmasında, modelin verimli, etkin ve ekonomik olduğu yönündeki gerekçelerin ayrıntılı analiz edilmediğine değinmiş ve projelerin mekânsal olarak ihtiyaçtan fazla büyük olduğunu, bu bağlamda da şehir hastanelerinin tedavi merkezinden ziyade beş yıldızlı otel konforunda 
ifadeleriyle ticari boyutunun vurgulandığını belirtmiştir. KÖO sözleşmelerinin kamuoyundan gizli tutulmasının ve özel sektöre ödenecek bedellerin açıklanmamasının ortaklığın kamuya getireceği yükün net olarak bilinmemesine sebep olduğunu vurgulamıştır. ${ }^{25}$

Yap-kirala-devret modeli ile yapılan şehir hastaneleri projelerinde, ortaklardan özel kesimin işletme döneminde elde edeceği kira gelirinden daha fazla istifade etmek için sözleşme süresini etkin şekilde kullanacağını belirten Kulaksız, sözleşme süreçlerinin karmaşık olmasının kamu kesimine düşen riski arttıracağına da değinmiştir. KÖO projelerinin hastane inşası projesinden öteye tıbbi hizmetler ve bilgi işlem altyapısının önemine değinen araştırmacı, ülkemizde uzun yıllardır modelin uygulandiğ 1 enerji ve ulaşım sektöründeki tecrübelerin sağlık sektörüne katkı sağlayacağını belirtmiştir. ${ }^{26}$

Erdem ise KÖO modelinin kamu maliyesine etkilerini incelemiş ve modelin, bütçeye yük olmadan sağlık hizmetlerinin sürdürülebilmesi, ortaklıktan toplumsal yarar elde edilmesi, yeni hizmet alanlarının doğması ile kamu maliyesine olumlu etkiler sağlayacağını vurgulamıştır. ${ }^{27}$

Özel sektörün sahip olduğu atıl sermayenin kamu hizmetinde kullanılması ile kamunun bu alandaki finansman sıkıntısına çözüm olacağını belirten Güler, şehir hastaneleri ile sağlık hizmetlerinin daha hızlı, etkili, kaliteli, ileri teknoloji ile verileceğini belirtmektedir. Modelin sağlık sektöründeki uygulamaları hakkında yetersiz bilgilendirmeye bağlı olarak eleştiri ve negatif görüşlerin hâkim olduğunu, konu kapsamında bilinç oluşturmak için gerekli çalışmaların yapılmasını önermektedir. ${ }^{28}$

Özkan entegre sağlık kampüslerinin standart yatan hasta odaları üzerine araştırma yapmış ve çalışmasında Bilkent Entegre Sağlık Kampüsü ile Ankara Numune Eğitim ve Araştırma Hastanesi'nin hasta odalarını kıyaslamıştır. Hasta odalarında kullanılan malzemeler, tasarım, teknik tesisat açısından Bilkent Entegre Sağlık Kampüsü'nde daha üstün kaliteli olduğu bulgusuna ulaşılmış, bu bulgulara dayanarak daha konforlu olduğu belirtilmiştir. $^{29}$

Ünal ve Ünal Trabzon ve Ankara'da toplamda 30 kamu hastanesinde yapmış oldukları çalışmada yöneticilerin kamu özel ortaklığ olduklarını ortaya koymuşlardır. Ayrıca, araştırmaya katılan yöneticilerin, kamu özel ortaklığında kamunun ağırlığının artması gerektiğini ifade ettiklerini, teknolojiye ve araştırma geliştirme faaliyetlerine daha fazla kaynak ayrılması gerektiği düşüncesine büyük oranda katıldıklarını, sözleşme sürelerinin uzaması durumunda kamu için ilave maliyetler oluşabileceğini ve dış kaynak kullanımının artması durumunda sağlık hizmetlerinin özel sektörün denetimine geçebileceğini vurgulamışlardır. ${ }^{17}$

$\mathrm{Bu}$ çalışma kapsamında ise bazı açılardan benzer bazı açılardansa farklı sonuçlara ulaşılmıştır. Yapılan analizler sonucunda yaş değişkeni ile KÖO eleştirileri ve sağlık hizmetleri finansman sorunları faktörleri arasında anlamlı bir alg1 farklılığ1 bulunmaktadır. KÖO eleştirileri en çok 26 'dan az yaş grubu ile 30-34 yaş grubu arasında alg1 farklılığ 1 göstermektedir. Sağlık hizmetlerinin finansman sorunu bakımından en büyük alg1 farklılığı 41'den büyük yaş grubu ile 27-29 yaş grubu arasındadır.

Cinsiyet ve KÖO eleştirileri arasındaki algı farklılığına bakıldığında erkeklerin kadınlara göre daha yüksek algılarının olduğu bulunmuştur. Bu bağlamda, erkeklerin KÖO için daha eleştirel bir yaklaşım içinde oldukları söylenebilir. Eğitim durumu açısından, üniversite mezunları ile lise mezunları arasında Türkiye'deki sağlık hizmetlerinin sunumu açısından anlamlı bir alg1 farklılığ sağlık hizmetlerinin finansman sorunlarına dair; lise ile yüksek lisans ve lise ile üniversite mezunları arasında alg1 farklılığı bulunduğu, yüksek lisans ile üniversite mezunları arasında bir alg1 farklılığı bulunmadığ tespit edilmiştir. Eğitim durumu ve sağlik hizmetlerinin verimliliği faktörü incelendiğinde, yalnızca yüksek lisans ile lise mezunları arasında bir alg1 farklılığı bulunduğu belirlenmiştir. 
Türkiye'de sağlık hizmetlerinin sunumuna ilişkin katılımcıların yanıtları, yönetici ile sağlık personeli, yönetici ile hemşire, yönetici ile doktor ve sağlik personeli ile doktor arasında farklılık göstermektedir. Bu durumda hizmet sunumuna ilişsin alg1 farklılığı asıl olarak yönetici pozisyonunda çalışanlar için geçerlidir. Sağlık hizmetleri sunumuna ilişkin alg1 farklılığ doktor ve hemşire-sağlı personelidir. Mesleki deneyim ve sağlik hizmetleri finansman sorunları arasındaki alg1 farklılığı incelendiğinde 16 ile 20 y1l arası mesleki deneyime sahip olanların en çok farklılık gösterdiği grup beş y1l ve daha az bir süredir sağllk sektöründe çalışanlar olarak bulunmuștur.

Türkiye'de sağlık harcamaları için devletin yeterli ödenek ayırmadığı, projelerin finansman sıkıntısı nedeniyle zamanında bitirilemediği ve sağlık hizmetlerinin kalite ve verimliliğinin yeterli düzeyde olmadığ yönünde görüşler çoğunlukta bulunmuştur. KÖO modeli ile yapılan şehir hastaneleri ile özel sektörün sahip olduğu sermayenin kullanılmasıyla daha ileri teknoloji ile sağlık hizmeti sunulacağı ve kamunun bu konudaki finansman sıkıntısına çözüm olabileceği öngörülmektedir.

\section{SONUC VE ÖNERÍLER}

Çalışmada oluşturulan beş hipotezin de farksızlık hipotezleri, oluşturulan faktörlere bağlı olarak reddedilmiştir. Katılımcıların verdiği yanıtlara göre yapılan analizde toplam altı adet faktör oluşturulmuş olup, bağımsız değişkenler ve KÖO ölçeği faktörlerinin ilişkilendirildiği alt hipotezlerin ayrıntılarına bulgular kısmında yer verilmiştir. $\mathrm{Bu}$ bulgulardan elde edilen temel sonuçları aşağıda yer aldığı gibi özetlemek mümkündür.

Bazı çalışmaların aksine, KÖO modeli konusunda çoğunluğun yeterli bilgiye sahip olmadığı ve KÖO konusunda yeteri kadar seminer, konferans ve benzeri bilgilendirme yapılmadığı tespit edilmiştir. Beş yıla kadar mesleki deneyime sahip çalışanlar haricindeki tüm sağlık çalışanları modelin özelleştirmenin farklı bir uygulaması olduğunu düşünmektedir. $\mathrm{Bu}$ türden eleştirilerin yoğunlaştığı yaş grubu 26 yaş altı çalışanlardır. Bununla birlikte, çalışmaya henüz başlamış beş ve daha az mesleki deneyime sahip olan katılımcılar ise eleștiri yapabilecek bir bilgiye sahip olamadıkları için KÖO'yu diğer mesleki çalışma sürelerine göre daha az eleştirmektedirler. $\mathrm{Bu}$ doğrultuda, sağlık çalışanlarının ve sağlık hizmeti alanların konu ile ilgili bilgilendirme çalışmalarının yapılması gerekliliği doğmaktadır. Kişilerin bilinçlendirilmesinin KÖO konusunda olumsuz görüş ve eleştirileri azaltacağı düşünülmektedir.
Araştırmaya katılan yöneticilerin Türkiye'de sağllk hizmetleri sunumunu diğer çalışanlara göre daha yetersiz bulduğu bulgusu elde edilmiştir. Yöneticilerin sağlık harcamaları için devletin yeterli ödenek ayırdığına, sağlık hizmetlerinden herkesin eşit şekilde yararlandığına ve sağlık hizmetinden halkın memnun olduğuna katılmadıkları belirlenmiștir. 41 ve üzeri yașta olanlar, sağl1k hizmetlerinin finansmanında sorunlar yaşandiğ 1 algısına diğer yaş gruplarına göre daha çok sahiptirler. Şehir hastanelerinde özel sektörün finansman desteği ile sağl1k harcamalarına daha yeterli ödenek aktarılarak hizmet kalitesi ve hasta memnuniyetinin artmas1 hedeflenmelidir. Projelerin uzun vadeli sözleşmelerle gerçekleştirilmesi nedeniyle ve suiistimallerin önlenmesi için sözleșmelerin her ayrıntıyı kapsamasına özen gösterilmelidir.

Üniversite mezunu katılımcılar şehir hastanelerinin daha çok kişinin iş sahibi olmasını sağlayarak istihdamı arttıracağını düşündüklerini belirtmişlerdir. Tıbbi destek hizmetlerinde özel kesimin taşeron işçi çalıştırması yerine tüm tıbbi hizmetlerin kamu tarafindan kamu personeli ile verilmesinin istihdamı daha fazla arttıracağı söylenebilir.

İleriki çalışmalara yön verebilmek adına bazı tespitlerde bulunabilir. Öncelikle, şehir hastanelerinde hizmet kalitesinin ve mekân kalitesinin ayrı olarak çalışılması önerilebilir. Böylece daha spesifik alg1 ve 
eleștiriler

bulunmaktadır.

Original Article karşılaştırmalara ulaşılabilir. Model hakkında, ülke kaynaklarının israf edileceği, özelleştirmeden farklı bir uygulama olmadığı, sağlık sektöründe gereksiz bir uygulama olduğu, uluslararası emperyalist sermayenin ülkeleri yeni bir sömürü şekli olduğu ve yolsuzlukları arttırabileceği yönünde giderilmesi için sözleșmeler ile ilgili kamuoyunun bilgilendirilmesinin yanında araştırmacılar açısından da bu unsurların içerildiği farklı ölçekler geliştirilmesi gereklidir.

KAYNAKLAR

1. Karasu, K. (2011). "Sağlık Hizmetlerinin Örgütlenmesinde Kamu-Özel Ortaklığı”. Ankara Üniversitesi SBF Dergisi, 66 (3), 217-262.

2. Akdağ, R. (2010). Türk Sağlık Sistemi'nde Kurum Dişından Hizmet Alım Uygulamaları: Araştırma Raporu. Ankara: Refik Saydam Hıfzıssıhha Merkezi Başkanlığı.

3. Acartürk, E. ve Keskin, S. (2012). "Türkiye'de Sağlık Sektöründe Kamu Özel Ortaklığı Modeli”. Süleyman Demirel Üniversitesi İ̈BF Dergisi, 17 (3), 25-51.

4. Altan, Y, Kerman, U, Aktel, M, Metin, Y. ve Eke, E. (2013) "Yerel Yönetimlerde Kamu Özel Ortaklığı Uygulaması: Büyükkabaca Belediyesi Örneği." Uluslararası Alanya İşletme Fakültesi Dergisi, 5 (3), 9-17.

5. Uygun, B. (2013). "Yeni Bir İlişski Türü: Kamu Özel Ortaklığı". Hukuk Gündemi, (2), 24-27.

6. Ayhan, E. ve Önder, E. (2018). “Türkiye'de Sağlık Sektöründe Kamu Özel Ortaklığı Modeli”. Uluslararası Sağlık Yönetimi ve Stratejileri Araștırma Dergisi, 4 (1), 514-526.

7. Özer, M.A. (2016). "Sağlık Sektöründe Yeni Bir Hizmet Sunum Modeli: Kamu Özel Ortaklığı”. Sosyal Güvenlik Dergisi, 6 (1), $9-38$

8. Tengilimoğlu, D, Işık, O. ve Akbolat, M. (2015). Sağlık Issletmeleri Yönetimi. Ankara: Nobel Yayın Dağıtım.

9. Yılmaz, Y.F. ve Karakaş, G.D. (2011). "Devlet/Kamu Üzerine Yeniden Düşünmek". Sağlık Alanında Kamu Özel Ortaklığı Sempozyumu: 2011 Mayıs 6-7; Bursa: Türk Tabipler Birliği Yayınları, 29-83.

10. Dönmez, N.F.K, Atalan, A. ve Dönmez, C.Ç. (2020) "Desirability Optimization Models To Create The Global Healthcare Competitiveness Index". Arabian Journal for Science and Engineering, (45), 7065-7076.

11. Gökkaya, D, Eroymak, S. ve İzgüden, D. (2018). "Kamu öze Ortaklığı Bağlamında Şehir Hastanelerinin Değerlendirilmesi" Social Sciences Studies Journal, 19 (4), 2235-2243.

12. Emek, U. (2017). "Sağlık Sektöründe Kamu Özel İşbirliği Sözleşmeleri: Beklenti Ve Gerçekleşme”. Hacettepe Hukuk Fakültesi Dergisi, 7 (1), 139-168.

13. Sağlık Bakanlığı. (2018). Adana Şehir Hastanesi haberi. Erişim adresi: https://sygm.saglik.gov.tr/TR-33024/kanal-24---adanasehir-hastanesi-haberi.html, (Erișim tarihi: 20.03.2021).

14. Raosoft. (2021). Sample Size Calculator. Erişim adresi: http://www.raosoft.com/samplesize.html, (Erisim tarihi: 20.03.2021)

15. Keskin, S. (2011). Türkiye'de Sağlık Hizmetlerinin Sunumunda Kamu Özel Ortaklığı Modeli (Aydın Örneği). Yüksek Lisans Tezi, Adnan Menderes Üniversitesi Sosyal Bilimler Enstitüsü, Aydin.

16. Ünal Köse, A. ve Kulakaç, N. (2019). "Kamu Hastaneleri Performans Ölçüm Yaklaşımının Sağlık Yöneticileri Tarafından Değerlendirilmesi”. Gümüşhane Üniversitesi Sağlık Bilimleri Dergisi, 8 (1), 18-24.
17. Ünal, A. ve Ünal, A.K. (2017). "Sağlık Sektöründe Kamu Özel Ortaklığına Yönelik Sağlık Yöneticilerinin Görüşleri”. Sağlık Akademisyenleri Dergisi, 4 (1), 51-56.

18. Çınar, N.F, Türkoğlu, C. ve Tütünsatar, A. (2017). "Kamu Özel Ortaklığı/Issbirliği Modeli Ve Sağlık Hizmetlerinin Sunumunda Hizmet Memnuniyetinin Ölçülmesi: Entegre Sağlık Kampüsleri (Sehir Hastaneleri) İçin Bir Araştırma”. Süleyman Demirel Üniversitesi Sosyal Bilimler Enstitüsü Dergisi, 29 (4), 215-232.

19. Medhekar, A. (2014). "Public Private Partner Ships For Inclusive Development: Role of Private Corporate Sector in Provision of Healthcare Service.". Procedia-Social and Behavioral Sciences, (157), 33-44.

20. Baş, Ö. (2018). Sağlık Sektöründe Kamu Özel Ortaklığı Modeli Hakkında Hizmet Sunucuları ve Hizmet Yararlanıcılarının Görüșlerinin Değerlendirilmesi: Yozgat İli Örneği. Yüksek Lisans Tezi, Atılım Üniversitesi Sosyal Bilimler Enstitüsü, Ankara.

21. Sadeghi, A, Barati, O, Bastani, P, Daneshjafari, D. and Etemadian, M. (2016). "Strategies To Develop and Promote Public-Private Partnerships in The Provision of Hospital Services in Iran: A Qualitative Study.” Electronic Physician, 8 (4), 2208-2214.

22. Top, M. and Sungur, C. (2019). "Opinions and Evaluations of Stakeholders in The İmplementation of The Public-Private Partnership Model in İtegrated Health Campuses (City Hospitals) in Turkey." The International Journal of Health Planning and Management (34), 241-263.

23. Tenşi, M. (2019). Sağlık Sektöründe Kamu Özel Ortaklığı Modelinin Şehir Hastaneleri Ekseninde Değerlendirilmesi: İzmir İli Alan Çalışması, Sıtkı Koçman Üniversitesi Sağlık Bilimler Enstitüsü, Yüksek Lisans Tezi, Muğla.

24. Lopez, M.R, Gorgemansb, S, Delgadoa, E.B. (2019). "Public Private Partnerships in The Spanish National Health System: The Reversion of The Alzira Model.” Health Policy, (123), 408-411.

25. Gökbulut, F. (2019). Türkiye'de Kamu Özel İșbirliğinin Sağlık Alanında Uygulanması: Sehir Hastaneleri. Yüksek Lisans Tezi, Ankara Üniversitesi Sosyal Bilimler Enstitüsü, Ankara.

26. Kulaksız, S. (2018). Kamu Hizmet Tedarik Yönteminin Belirlenmesinde Kamu Özel İsbirliği Yöntemi Ve Geleneksel Tedarik Yönteminin Bir Sağlık Sektörü Projesi Üzerinde İncelenmesi. Doktora Tezi, Baskent Üniversitesi Sosyal Bilimler Enstitüsü, Ankara.

27. Erdem, E. (2015). Sağlık Hizmetinde Kamu Özel Ortaklığı Modelinin Kamu Maliyesine Etkileri. Yüksek Lisans Tezi, Dokuz Eylül Üniversitesi Sosyal Bilimler Enstitüsü, , İzmir.

28. Güler, E. (2016). Sağlık Hizmetlerinde Kamu Özel Ortaklığ Modeli (Bursa İli Örneği). Yüksek Lisans Tezi, Atılım Üniversitesi Sosyal Bilimler Enstitüsü, Ankara.

29. Özkan, S. (2018). Türkiye'de Kamu Özel Ortaklı̆̆ı Entegre Sağlık Kampüsleri Standart Yatan Hasta Odaları Üzerine Bir İnceleme. Yüksek Lisans Tezi, Hacettepe Üniversitesi Güzel Sanatlar Enstitüsü, Ankara. 